\title{
A dimensionless parametric study on the performance of a single-effect solar still
}

\author{
Um estudo paramétrico adimensional sobre o desempenho de um destilador solar de efeito único \\ Un estudio paramétrico adimensional sobre el rendimiento de un destilador solar de efecto único
}

Received: 12/18/2020 | Reviewed: 12/26/2020 | Accept: 01/11/2021 | Published: 01/13/2021

\author{
Antônio Marcos de Oliveira Siqueira \\ ORCID: https://orcid.org/0000-0001-9334-0394 \\ Federal University of Viçosa, Brazil \\ E-mail: antonio.siqueira@ufv.br \\ Fernando Ariel Colque \\ ORCID: https://orcid.org/0000-0003-2599-4307 \\ Universidad Nacional de Salta, Argentina \\ E-mail: fernandocolq@gmail.com \\ Gabriel Siqueira Silva \\ ORCID: https://orcid.org/0000-0002-2462-9263 \\ Federal Center for Technological Education of Minas Gerais, Brazil \\ E-mail: gabrielsiqueira25@outlook.com \\ Alexandre Gurgel \\ ORCID: https://orcid.org/0000-0002-3120-8168 \\ Federal University of Viçosa, Brazil \\ E-mail: agurgel@ufv.br \\ Júlio Cesar Costa Campos \\ ORCID: https://orcid.org/0000-0002-9488-8164 \\ Federal University of Viçosa, Brazil \\ E-mail: julio.campos@ufv.br
}

\begin{abstract}
Research on the design and operation of solar stills is relatively advanced, but many works have focused only on the description of the individual behavior and operation of experimental apparatus that can be operated under specific experimental or natural conditions. In any case, optimization of the systems requires the correlation of several parameters by means of mathematical modeling, which can be relatively complex. In this work, appropriate global normalization of governing mathematical equations employing dimensionless numbers has been successfully applied for the versatile operation of solar stills. In this novel approach, optimized conditions to design efficient solar stills are presented and discussed. The results also indicated that the generalized dimensionless model could be able of predicting the still performance. The reasons and processes behind the changing trends of the results depend on the simple analysis of the corresponding nondimensional number.
\end{abstract}

Keywords: Solar still; Desalination; Similarity theory; Dimensional analysis.

\section{Resumo}

A pesquisa sobre o projeto e a operação de destiladores solares está relativamente avançada, mas muitos estudos têm focado apenas na descrição do comportamento individual sob condições experimentais específicas. Em qualquer caso, a otimização dos sistemas requer a correlação de vários parâmetros por meio de modelagem matemática, o que pode ser uma abordagem relativamente complexa. Neste trabalho, a normalização apropriada das equações matemáticas que regem os fenômenos de transferência de calor e de massa, foi aplicada para a operação genérica de destiladores solares, com o emprego de números adimensionais. Nesta nova abordagem, as condições otimizadas para o projeto de destiladores solares são apresentadas e discutidas. Os resultados do estudo também indicaram que o modelo adimensional generalizado é capaz de predizer o desempenho das instalações, que pode ser justificado pela interpretação dos o números adimensionais correspondentes a dada configuração.

Palavras-chave: Destilador solar; Dessalinização; Teoria da similaridade; Análise dimensional.

\section{Resumen}

La investigación sobre el diseño y el funcionamiento de destiladores solares está relativamente avanzada, pero muchos trabajos se han centrado únicamente en la descripción del comportamiento individual y el funcionamiento de aparatos experimentales que operan pueden funcionar en condiciones experimentales o naturales específicas. En cualquier caso, la optimización de los sistemas requiere la correlación de varios parámetros mediante modelos matemáticos, que pueden resultar relativamente complejos. En este trabajo, se ha aplicado con éxito la normalización global apropiada de las ecuaciones matemáticas que rigen en el fenómeno, con el empleo de números adimensionales, para la operación genérica de los destiladores solares. En este enfoque novedoso, se presentan y discuten las condiciones optimizadas para diseñar destiladores solares eficientes. Los resultados también indicaron que el modelo adimensional generalizado 
podría predecir el rendimiento estático. Las razones y procesos detrás de las tendencias cambiantes de los resultados dependen del simple análisis del número adimensional correspondiente.

Palabras clave: Destilador solar; Desalinización; Teoría de la similitude; Análisis dimensional.

\section{Introduction}

Solar stills are exceptional devices for producing potable water, particularly in rural communities, and enable solarpowered desalination based on principles that are essentially simple, whereby solar energy directly effects evaporation of water (Elango et al., 2015; Mohan et al., 2019; Rufuss et al., 2016). In special, single-effect solar stills consist of a basin that accommodates brackish water and is covered by one or two sloping covers. The water in the basin is heated by the incident solar radiation transmitted through the transparent cover, and then evaporates, condenses and flows across the inside of the cover, being finally collected on the opposite side. According to Agrawal and Rana (2019), Gnanaraj and Velmurugan (2019), Tripathi and Tiwari (2006), and Velmurugan and Srithar (2011), the daily productivity of conventional solar still is in the range of 2-5 kg $\mathrm{m}^{-2}$.

Several review papers have been reported in the literature focusing on experimental and numerical investigations with solar stills (Ahmed \& Alfaylakawi, 2012; Ahsan et al., 2012; Al-Hayeka \& Badran, 2004; Al-Hinai et al., 2002; Al-Karaghouli et al., 2009; Arunkumar et al., 2012; El-Bahi \& Inan, 1999; El-Ghonemy, 2012; Elkader, 1998; Eze \& Ojike, 2012; Karagiannis \& Soldatos, 2008; Panchal \& Shah, 2011; Radhwan, 2005; Rajan et al., 2014; Rajaseenivasan et al., 2013; Rajaseenivasan et al., 2014; Sivakumar et al., 2013; Varun, 2010; Velmurugan et al., 2008; Xiao et al., 2013). However, most of these investigations consider only the individual rather than the global behavior of a conventional solar still. Muftah et al. (2014) show that the distillation productivity of a solar still is significantly affected by climatic, operational and design parameters.

Many of such reports in the literature have demonstrated that the productivity and performance of solar stills depend on parameters like solar radiation, wind velocity, basin water depth, temperature difference between the cover plate and water, cover thickness, cover inclination, bottom insulation, and geometry of the equipment (Ayoub et al., 2015; Dunkle, 1961; Edalatpour et al., 2016; Gnanaraj \& Velmurugan, 2019; Khalifa \& Hamood, 2009; Kumar et al., 2015; Mowla \& Karimi, 1995; Nguyen et al., 2017; Omara et al., 2017; Rahbar et al., 2015; Raj and Manokar, 2017; Rashidi et al., 2017; Rufuss et al., 2016; Sarkar et al., 2017; Selvaraj \& Natarajan, 2018; Tayeb, 1992).

As properly pointed out by Rufuss et al. (2016), "the goal of implementing solar stills at commercial scale remains elusive mainly because of their limited output", and "for successful implementation, researchers continue to investigate a wide range of innovations in solar stills, based on operating parameters, geometry, system configuration and materials”. Despite the numerous, extensive studies on the design and performance of solar stills, the necessity to comparatively elucidate analytical results of individual experiments carried out under different meteorological, operational and geometric conditions is evident (Mashaly, 2015; Tsilingiris, 2009). The use of dimensional analysis is a relatively good tool to accomplish this.

There are many advantages to using solar stills in water treatment processes, but these are hindered by insufficient knowledge on the global behavior of such equipment. Therefore, the present paper aims to present a dimensionless parametric study on the performance of a single-effect solar still and to determine the influence of each characteristic parameter on its design and optimization.

\section{Similarity Theory of Solar Stills}

In chemical engineering, mechanical engineering, fluid mechanics, and heat and mass transfer problems, the use of dimensionless (or nondimensional) numbers, such as the Reynolds number, Nusselt number and Biot number, is very common (Bergman, Lavine \& Incropera, 2011; Çengel a\& Boles, 2008; Welty et al., 2007). According to Kunes (2012), the 
“dimensionless quantity expresses either a simple ratio of two dimensionally equal quantities (simple) or that of dimensionally equal products of quantities in the numerator and in the denominator (composed)".

Ruzicka (2008) also proposed that dimensionless numbers that express or refer to specific criteria, groups, products, quantities, ratios or terms can be given as algebraic expressions or fractions, whose numerator and denominator are powers of physical quantities, being the total physical dimension equal to unity. The dimensional analysis of mathematical equations (or systems of equations) by inspection is also known as "normalization" or "nondimensionalization", and constitutes a very useful technique in engineering studies that can be undertaken with the use of dimensionless groups (Bergman, Lavine \& Incropera, 2011; Çengel \& Boles, 2008; Ruzicka, 2008; Welty et al., 2007).

The main purpose of dimensional analysis is to reduce the number of variables involved in a mathematical model by introducing independent dimensionless groups of variables (or dimensionless parameters). The nondimensionalization (or normalization) is based in inspectional analysis and previous selection of dimensionless groups, using the Buckingham $\pi$ theorem (Bergman, Lavine \& Incropera, 2011; Buckingham, 1914; Çengel \& Boles, 2008; Ruzicka, 2008; Welty et al., 2007; Yarin, 2012). The developed dimensional analysis allows to: (a) generate nondimensional parameters that can help in the design of physical and/or numerical experiments, and (b) obtain scaling laws so that the prototype performance (sizing) can be predicted from the model performance.

In this section, the primary theory of temperature-distribution conversion is described, followed by the conversion of the withdrawn-water temperature. Finally, the similarity theory is verified. The simplified schematic view of solar still considered is shown in Figure 1.

Figure 1 - Schematic view of a solar still.

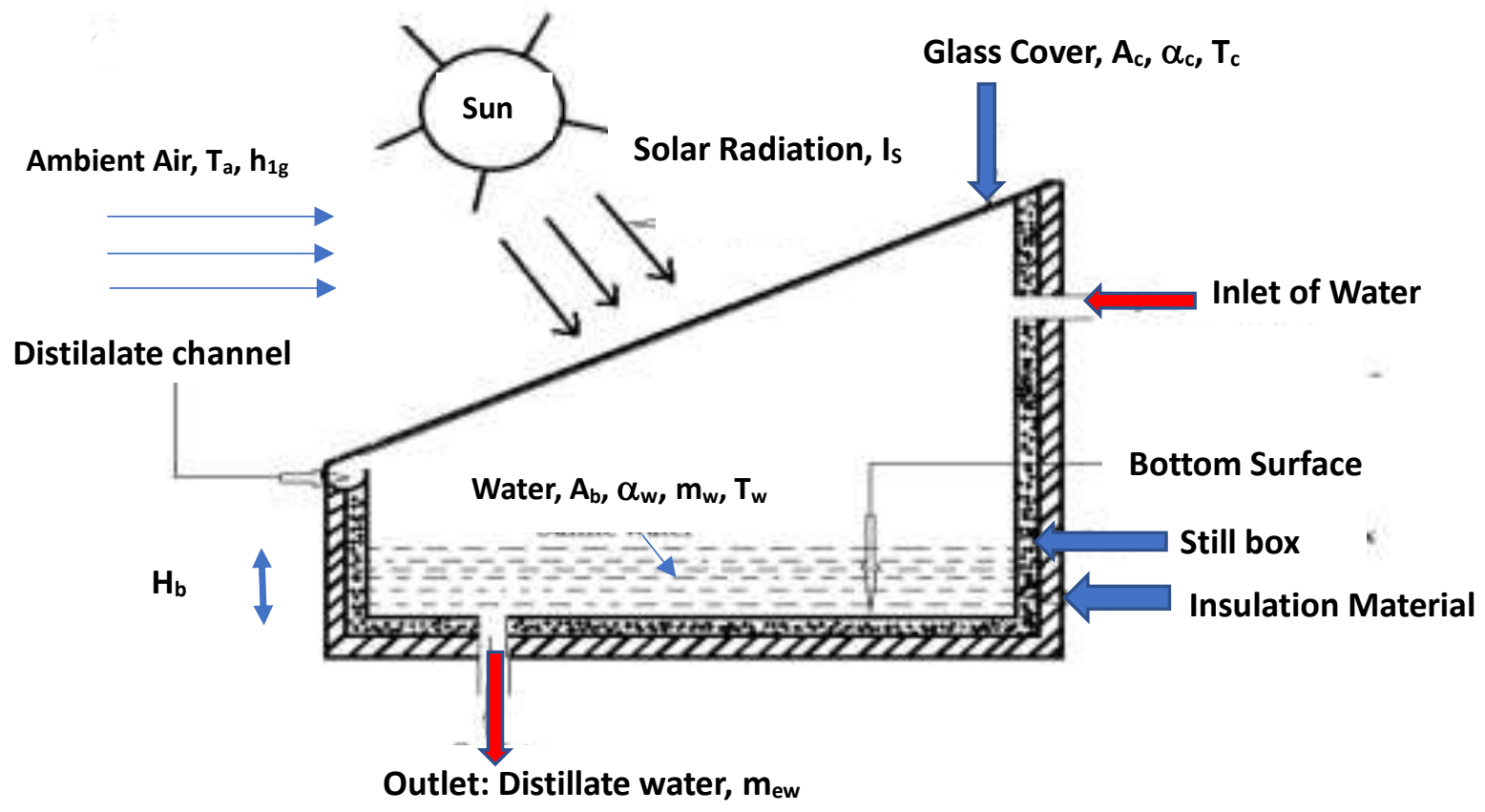

Source: Authors.

\subsection{Dimensional Mathematical Modeling}

In order to simplify the mathematical modeling analysis, the following assumptions are considered:

I. The level of water in the basin is maintained at a constant level;

II. Film-type condensation occurs at the glass trough;

III. The heat capacity of the cover is negligible; 
IV. There is no vapor leakage in the still;

V. There is no temperature gradient across the glass cover thickness, nor throughout the water sample used in the studies.

VI. The system operates in a quasi-static condition.

\subsubsection{Heat Transfer on the Cover Surface}

According to Afrand et al. (2016), Al-Hinai et al. (2002), Elango et al. (2015), Madhlopa and Johnstone (2009), Mowla and Karimi (1995), Nguyen et al. (2017), Sarkar et al. (2017), Selvaraj and Natarajan (2018), Varun (2010), and Xiao et al. (2013), the energy balance on the cover of the solar still can be represented by Equation 1.

$\alpha_{c} I_{s} A_{c}+h_{t w}\left(T_{w}-T_{c}\right) A_{b}=h_{1 g}\left(T_{c}-T_{a}\right) A_{c}$

The first term refers to the radiated heat on the cover. The second term refers to heat transfer between the water surface and cover surface. And finally, the right portion represents the heat lost by the cover to the environment, involving convection and thermal radiation. Where:

$\alpha_{c}=$ Absorptivity of the cover $\left[\mathrm{J} \mathrm{kg}^{-1}\right]$;

$I_{s}=$ Solar radiation $\left[\mathrm{W} \mathrm{m}^{-2}\right]$;

$A_{c}=$ Cover surface area $\left[\mathrm{m}^{2}\right]$;

$A_{b}=$ Area of the basin of the still, $\left[\mathrm{m}^{2}\right]$;

$h_{t w}=$ Total heat transfer coefficient from the water surface to the cover surface $\left[\mathrm{W} \mathrm{m}^{-2} \mathrm{~K}^{-1}\right]$;

$T_{w}=$ Basin water temperature $[\mathrm{K}]$;

$T_{c}=$ Cover temperature $[\mathrm{K}]$;

$T_{a}=$ Ambient temperature $[\mathrm{K}]$;

$h_{1 g}=$ Convective heat transfer coefficient between the cover and the surroundings [W $\left.\mathrm{m}^{-2} \mathrm{~K}^{-1}\right]$.

The total heat transfer coefficient from the water surface to the cover surface is given by $h_{t w}=h_{r w}+h_{c w}+h_{e w}$ (Duffie and Beckman, 1991; Elango et al., 2015; Tiwari and Sahota, 2017). The expressions for Convective ( $h_{c w}$ ), thermal radiative $\left(h_{r w}\right)$ and evaporative $\left(h_{e w}\right)$ heat transfer coefficient from the water mass in the basin to the condensing cover could be calculated from analyses reported by Shawaqfeh and Farid (1995), Tiwari et al. (2009), Tsilingiris (2010), Tsilingiris (2011), Tsilingiris (2012), and Voropoulos et al. (2000).

\subsubsection{Heat Transfer in the Water in the basin}

The heat energy is absorbed by the basin water due to fraction of transmitted solar radiation striking on it and it is absorbed by water. The absorbed heat energy is consumed in three ways, a) one part is stored in water due to its specific heat; b) part of heat energy is transferred from water surface to the glass cover by convection, evaporation and radiation, and c) remaining heat is lost from basin liner to atmosphere through the bottom and sides of the solar still by conduction and convection (Agrawal et al., 2017; Al-Hinai et al., 2002; Madhlopa \& Johnstone, 2009; Mowla \& Karimi, 1995; Nguyen et al., 2017; Rahbar et al., 2015; Sarkar et al., 2017; Selvaraj \& Natarajan, 2018; Varun, 2010; Xiao et al., 2013).

$\alpha_{w}=$ Absorptivity of the water;

$c p_{w}=$ Specific heat of water $\left[\mathrm{J} \mathrm{kg}^{-1} \mathrm{~K}^{-1}\right]$; 
$m_{w}=$ Mass of water in the basin $[\mathrm{kg}]$;

$U_{s}=$ Heat loss coefficient from the insulation $\left[\mathrm{W} \mathrm{m}^{-2} \mathrm{~K}^{-1}\right]$.

$\alpha_{w}\left(1-\alpha_{c}\right) I_{s} A_{b}=m_{w} c p_{w}\left[\frac{d T_{w}}{d t}\right]+h_{t w}\left(T_{w}-T_{c}\right) A_{b}+U_{s}\left(T_{w}-T_{a}\right) A_{b}$

The term on the left-hand side of Equation 2 refers to the amount of heat radiated to the surface of the water. The first term on the right-hand side refers to heat stored in the water. The second term on the right-hand side refers to the heat transferred between the water surface and the cover surface. Finally, the last term on the right represents heat loss from the insulation. The adopted mathematical model is quasi-steady-state approximation and Equation 2 is in dynamic mode, because the energy stores in the basin, and there is a variation in the water temperature. The heat capacities of the glass cover, the absorbing material, and the insulation are negligible.

\subsubsection{Condensate Water Mass Flow}

The mass flow of condensate water is expressed by Equation 3, which is obtained by calculating the amount of heat that flows from the brine to the cover by evaporation:

$\dot{m}_{e w}=\frac{A_{c} h_{e w}\left(T_{w}-T_{c}\right)}{h f g}$

where $h f g$ is the latent heat of vaporization $[\mathrm{Jkg}]$.

\subsubsection{Performance of Solar still}

The efficiency of a solar still is defined as the ratio of the heat transfer in the still by evaporation-condensation to the radiation on the still. The cumulative efficiency of solar still is mathematically expressed by:

$\eta_{T}=\frac{\sum \dot{m}_{e w} h f g}{\sum\left(I_{s} A_{c}\right)}$

There is a close agreement between the theoretical results and experimental data for a conventional solar still, using this classical dimensional mathematical model (Elango et al., 2015; Gnanaraj and Velmurugan, 2019).

\subsection{Normalized Mathematical Modeling}

Equations 1, 2, 3 and 4 can be normalized to generate the following set of equations:

$\frac{G^{*}}{C_{w c}^{*}}+B i^{w} \theta_{w c}=B i_{w i n d} G^{*} \theta_{c a}$

$\frac{1}{C_{w w}^{*}}=Z_{H} \frac{d \theta_{w}}{d F o_{w}}+B i^{w} \theta_{w c}+B i_{\text {Loss }} \theta_{w a}$

$\zeta=G^{*} \theta_{w c}$ 
$\eta_{T}=\frac{\zeta B i_{e}^{w}}{G^{*}} C_{w c}^{*} \alpha_{c}$

The normalized equations, which represent the process of evaporation and condensation of water in the solar still, can be written as a function of six (6) dimensionless groups, defined by equations 9 to 14 . These parameters can properly characterize the phenomenon and can be used in more general analytical processes, thereby providing ideal conditions for the design and optimization of the equipments.

$Z_{H} \equiv \frac{H_{b}}{\overline{H_{b}}}$

$G^{*} \equiv \frac{A_{c}}{A_{b}}$

$C_{w c}^{*} \equiv \frac{k_{w}\left(T_{w i}-\bar{T}_{a}\right) / \overline{H_{b}}}{\alpha_{c} I_{s}}$

$B i_{\text {Loss }} \equiv \frac{U_{s} \overline{H_{b}}}{k_{w}}$

$B i_{\text {wind }} \equiv \frac{h_{1 g} \overline{H_{b}}}{k_{w}}$

$F o_{w} \equiv \frac{\alpha t}{{\overline{H_{b}}}^{2}}$

The Areas Ratio Number $\left(G^{*}\right)$ is a geometric dimensionless group that represents the ratio between the area of the cover surface $\left(A_{c}\right)$ and that of the basin water $\left(A_{b}\right)$. It is a useful parameter to evaluate the effect of changing the area of the cover surface.

The dimensionless Water Basin Number $\left(Z_{H}\right)$ which represents the ratio between the thickness of the water film $\left(H_{b}\right)$ in the basin of the solar still and a "reference" water depth $\left(\overline{H_{b}}=0.01 \mathrm{~m}\right)$, which is a more common value used in similar experiments with this type of system, according to the scientific community (Al-Hinai et al., 2002; Garg and Mann, 1976; Khalifa and Hamood, 2009; Nguyen et al., 2017; Rahbar et al., 2015; Sarkar et al., 2017; Selvaraj and Natarajan, 2018; Tiwari and Tiwari, 2007; Xiao et al., 2013; Varun Raj and Manokar, 2017).

The dimensionless Solar Radiation Number $\left(C_{w c}^{*}\right)$ represents the amount of heat transferred by conduction in the basin water having solar energy as the main reference. And it is related to the Jakob Number $(\mathrm{Ja})$, and unnamed dimensionless groups $\pi_{a}$ and $\pi_{b}$.

$C_{w c}^{*} \equiv J a \pi_{a} \pi_{b}$

The Jakob number (Ja) is the ratio between the maximum sensible energy absorbed by the liquid (vapor) and the latent energy absorbed by the liquid (vapor) during evaporation/condensation. In many applications, the sensible energy is much lower than the latent energy, and Ja is accordingly low, as pointed out by Bergman, Lavine and Incropera (2011), Çengel and Boles (2008), and Welty et al., (2007), a "very small Jacob number may be thought of as a very large value of the latent heat, which will tend to limit the volume change of the bubbles due to evaporation or condensation". The Jakob number can be expressed by 
Equation 16:

$J a \equiv \frac{c p_{w}\left(T_{w i}-\bar{T}_{a}\right)}{h f g}$

The mathematical representations of the unnamed dimensionless groups $\pi_{a}$ and $\pi_{b}$ are given by Equations 17 and 18 :

$\pi_{a} \equiv \frac{\rho_{w} h f g^{3 / 2}}{\alpha_{c} I_{s}}$

$\pi_{b} \equiv \frac{\propto}{\overline{H_{b}} h f g^{1 / 2}}$

where $\rho_{w}$ is the specific mass of water $\left[\mathrm{kg} \mathrm{m}^{-3}\right]$. The unnamed dimensionless group $\pi_{a}$ establishes the ratio between the energy required for phase change and the corresponding heat transfer rate, and $\pi_{b}$ relates the water thermal diffusivity $(\alpha)$ and the latent heat of vaporization.

The heat transfer Biot Number $(B i)$ may be interpreted as a ratio of thermal resistances, and it is a dimensionless representation of whether the internal conduction or the external heat transfer is dominating the process while it occurs (Bergman, Lavine and Incropera, 2011; Çengel and Boles, 2008; and Welty et al., 2007). Therefore, the Loss Biot Number (Bi $i_{\text {Loss }}$ ) could be interpreted as a ratio between the reference conductive resistance within a water body and the thermal loss from the water basin to the environment. It is a measure of the heat loss to the environment.

Similarly, the Wind Biot Number $\left(B i_{\text {Wind }}\right)$ is the ratio between the reference conductive resistance within a water body in the solar still basin and the heat transferred by convection and thermal radiation from the cover surface to the environment.

Finally, the Fourier Number $\left(F o_{w}\right)$ represents the dimensionless time required to change the water temperature in the basin of the solar still, and can be calculated from the thermo-physical properties of the material and its characteristic dimensions. This parameter controls the thermal transient behavior.

The five response dimensionless groups that must be used to enhance the performance of the solar still are the following:

i. Dimensionless temperature difference between water in the basin and ambient environment $\left(\theta_{\mathrm{wa}}\right)$;

ii. Dimensionless temperature difference between water and cover $\left(\theta_{\mathrm{wc}}\right)$;

iii. Dimensionless condensate mass flow $(\zeta)$;

iv. Efficiency $\left(\eta_{\mathrm{T}}\right)$, and

v. Water Biot Number $\left(B i^{w}\right)$.

The dimensionless temperature differences are defined with Equations 19 to 22. The dimensionless condensate mass flow (z) is defined by Equation 23 and the Water Biot Number can be calculated with Equation 24.

$\theta_{w c} \equiv \frac{\left(T_{w}-T_{c}\right)}{\left(T_{w i}-\bar{T}_{a}\right)}$

$\theta_{w} \equiv \frac{\left(T_{w}-\bar{T}_{a}\right)}{\left(T_{w i}-\bar{T}_{a}\right)}$ 
$\theta_{c a} \equiv \frac{\left(T_{c}-T_{a}\right)}{\left(T_{w i}-\bar{T}_{a}\right)}$

$\theta_{w a} \equiv \frac{\left(T_{w}-T_{a}\right)}{\left(T_{w i}-\bar{T}_{a}\right)}$

$\zeta \equiv \frac{\dot{m}_{e w} h f g}{h_{e w} A_{b}\left(T_{w i}-\bar{T}_{a}\right)}$

$B i^{w} \equiv \frac{H_{b} h_{t w}}{k_{w}}=B i_{r}^{w} B i_{c}^{w} B i_{e}^{w}$

where: $T_{w i}$ is the reference basin water temperature $[\mathrm{K}]$; and $\bar{T}_{a}$ is the reference ambient temperature $[\mathrm{K}]$. The dimensionless condensate mass flow $(\mathrm{z})$ is the nondimensional representation of the yield of the solar still. The condensate mass flow depends on many parameters, including the performance of solar stills, according to Equation 8 . The dependence of performance on water depth is discussed in section 4 .

The Water Biot Number $\left(B i^{w}\right)$ shows the ratio between the reference conductive resistance within a water body and the convective-radiative-evaporative resistance outside the water body. Three parameters contribute to the final value of $B i^{w}$, namely the thermal radiation, convection and evaporation, which respectively define the Radiative Water Biot Number $\left(B i_{r}^{w}\right)$, the Convective Water Biot Number $\left(B i_{c}^{w}\right)$, and the Evaporation Water Biot Number $\left(B i_{e}^{w}\right)$. Equations 25-27 express these contributions.

$B i_{r}^{w} \equiv \frac{h_{r w} \overline{H_{b}}}{k_{w}}$

$B i_{c}^{w} \equiv \frac{h_{c w} \overline{H_{b}}}{k_{w}}$

$B i_{e}^{w} \equiv \frac{h_{e w} \overline{H_{b}}}{k_{w}}$

In dimensionless parametric studies, it is sufficient to consider that internal and external heat transfer coefficients could be represented by average values (for example, within one day). The mathematical study permits, if necessary, to adopt dimensionless numbers that are different for each hour. However, in this paper, this is not considered, because one important focus is only on the generalization of the results. And, for this study, it is not necessary to calculate (or estimate) the values for heat transfer coefficients. The idea is to consider a universal number, such as the Reynolds Number or the Stanton Number. In this analysis, the Wind Biot Number and the Water Biot Number have proven to be representative for the distillation process.

\section{Implementation}

The resulting dimensional and nondimensional algebraic and differential equations have been numerically solved with an adequate iterative method for temporary discretization. A computer program has been developed in the application software Engineering Equation Solver - EES (Dash, 2014), using the implemented Explicit-Euler-Method and/or the Crank-NicholsonMethod and self-written functions. The main purpose of this simulation was to carry out a nondimensional parametric analysis of a classic solar still in order to determine the influence of various dimensionless quantities on the thermal performance of a 
solar still.

In this work, a representative database of weather data for the 1-year duration, known as Typical Meteorological Year (TMY), has been employed. Kalogirou (2003) defines a TMY as a year which sums up all the climatic information characterizing a period as long as the average life of the system. This database is an appropriate meteorological set of data for long-term predictions of the annual performance of solar energy systems (Argiriou et al., 1999; Martins et al., 2012; Zhou et al., 2010).

\section{Results and Discussion}

In the present analysis, the similarity theory of the solar still has been developed and eleven (11) global dimensionless groups (characteristic numbers) have been derived, by normalizing the governing equations. The performance of the system, which ultimately determines the efficiency of the condensate water to flow, is a unique function of these parameters. The basis of the similarity theory of the solar still is therefore established herein. The similarity solutions could be used in the analysis of the performance of the solar still and when sizing or designing the system, using some important design rules.

Besides the Fourier Number, the characteristic parameters to be considered in the parametric analysis are $Z_{H}, G^{*}, C_{w c}{ }^{*}$, $B i_{\text {Loss }}$ and $B i_{\text {Wind }}$. The response dimensionless groups that ensure the solar still performance are $\mathrm{q}_{\mathrm{wa}}, \mathrm{q}_{\mathrm{wc}}, \mathrm{z}, \mathrm{h}_{\mathrm{T}}$, and $B i^{w}$. To analyze the results, numerical computation has been carried out, using the method described in the previous section for fixed and/or median governing parameters.

According to Figure 2, $Z_{H}$ has significant effects on the performance of the solar still. By increasing the water depth in the basin, the efficiency and the dimensionless condensate mass flow are decreased. This parameter controls the quantity of mass in the basin during the evaporation process and the conductive thermal resistance in the basin, according to mathematical modeling for distillation processes.

Figure 2 - Effect of water depth in the basin $\left(Z_{H}\right)$ on the efficiency of a solar still.

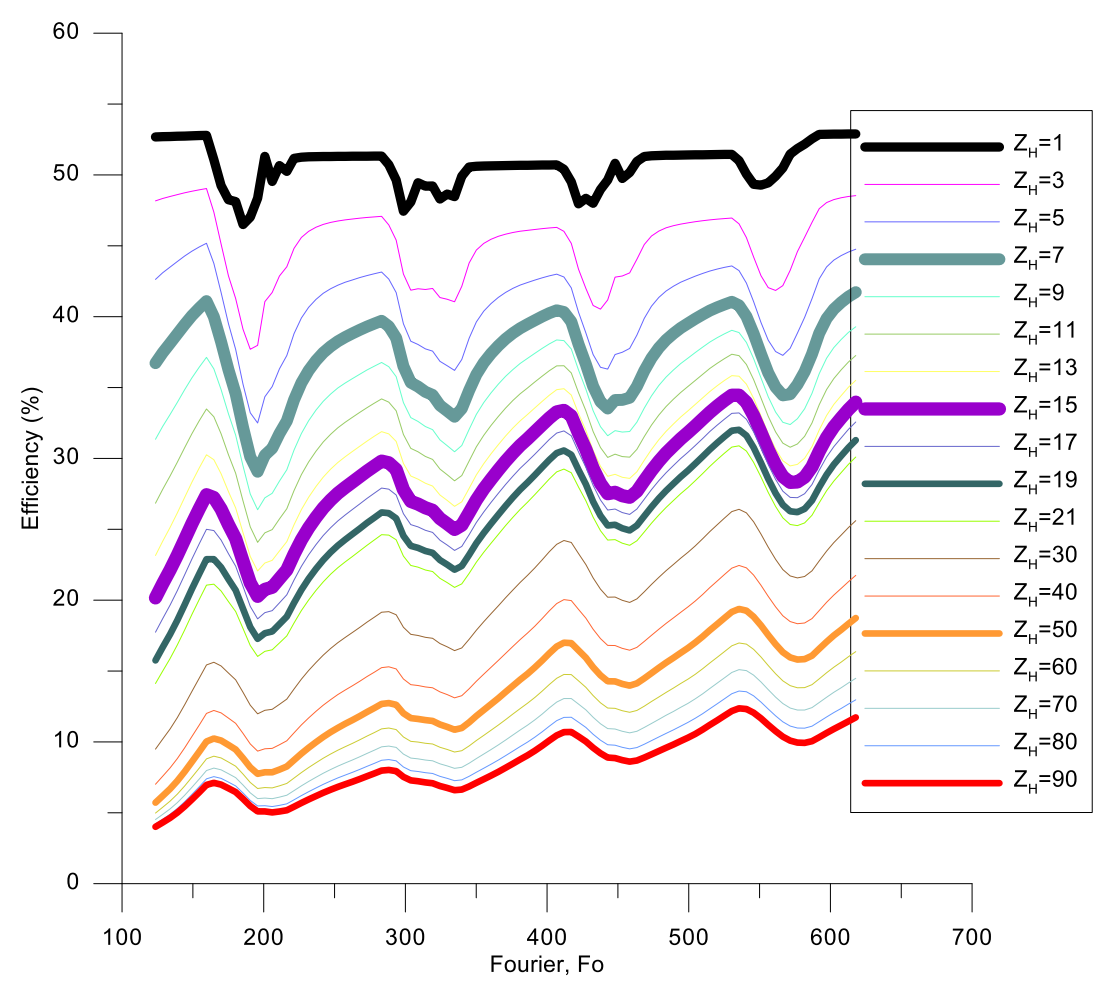

Source: Authors. 
This result indicates that the relative water depth is the most important parameter in the analysis of a solar still. It is possible to observe, for example, that from $Z_{H}=1$ to $Z_{H} » 10$ the efficiency decreases from $50 \%$ to about $45 \%$, and from $Z_{H}=$ 1 to $Z_{H} \gg 90$, the efficiency decreases from $50 \%$ to about $10 \%$. This result is consistent with several experiments and simulation results (Garg and Mann, 1976; Al-Hinai et al., 2002; Tiwari and Tiwari, 2007; Xiao et al., 2013; Rahbar et al., 2015; Nguyen et al., 2017; Sarkar et al., 2017; Selvaraj and Natarajan, 2018; Varun Raj and Manokar, 2017).

In addition, Figure 3 shows the profiles of the efficiencies and the dimensionless temperature differences between water in the basin and ambient environment for $\mathrm{ZH}=1,11,50$ and 90. For lower $\mathrm{ZH}$ values, higher dimensionless temperature differences between water in the basin and ambient environment are affected, and the efficiencies are consequently higher. Even in the case of $\mathrm{ZH}=1$, which means that the water depth is very low $(=0.01 \mathrm{~m})$, the efficiency is slightly dependent on the meteorological data (solar radiation, ambient temperature and wind velocity), and it is not much affected by the Fourier number.

Figure 3a - Motion of the efficiency and dimensionless water temperature difference, for $Z_{H}=1$.

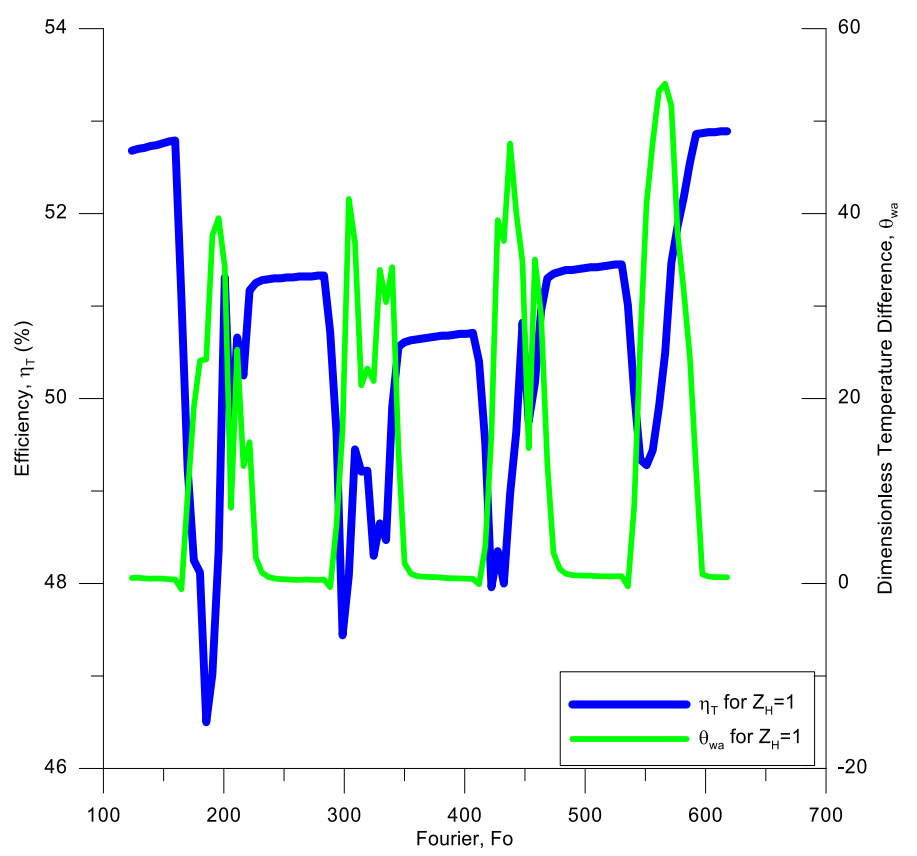

Source: Authors. 
Figure 3b-Motion of the efficiency and dimensionless water temperature difference, for $Z_{H}=11$.

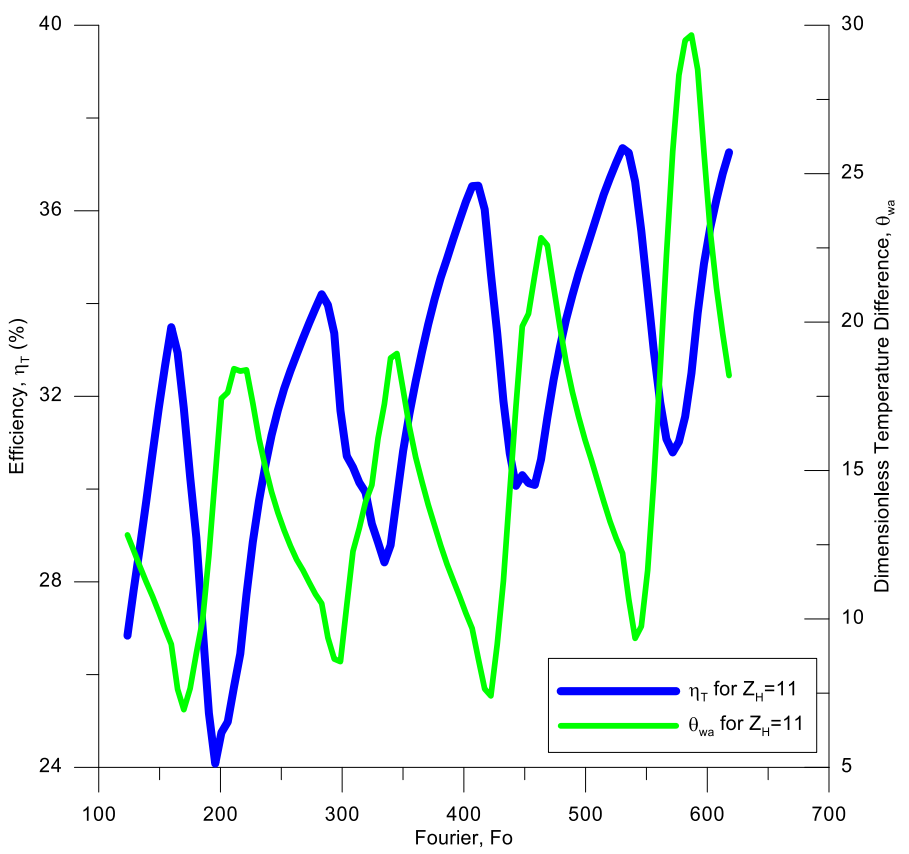

Source: Authors.

Figure 3c - Motion of the efficiency and dimensionless water temperature difference, for $Z_{H}=50$.

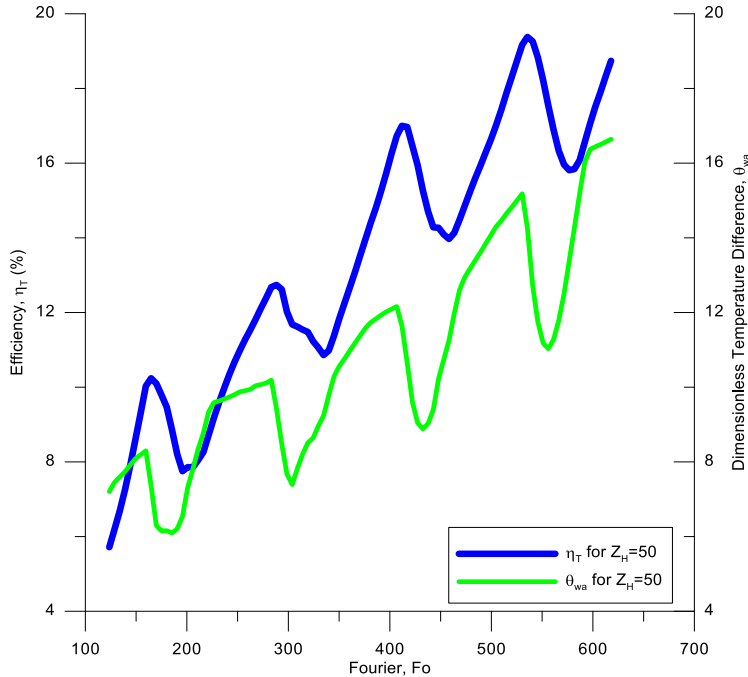

Source: Authors. 
Figure 3d - Motion of the efficiency and dimensionless water temperature difference, for $Z_{H}=90$.

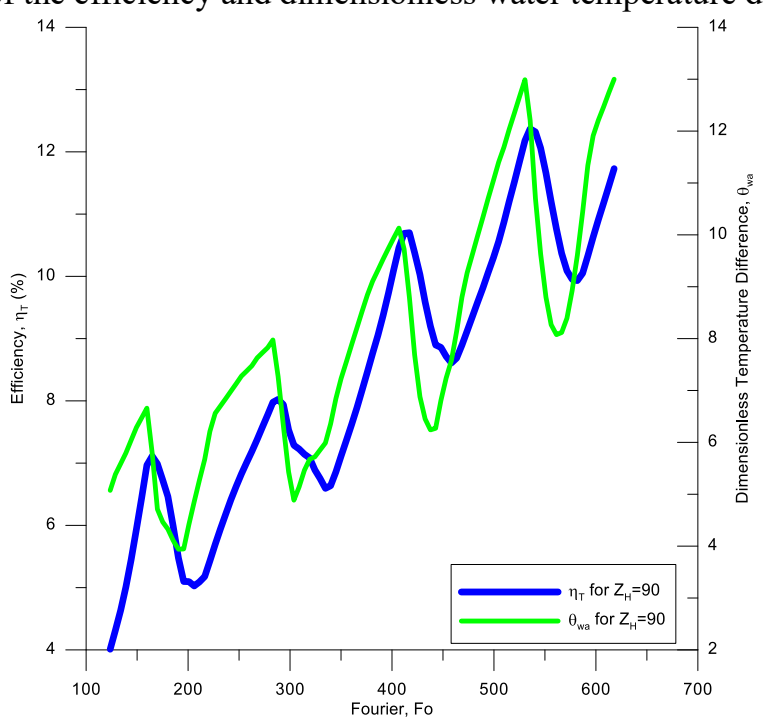

Source: Authors.

Therefore, it is possible to conclude that, in order to reduce the influence of meteorological conditions during a typical experimental procedure in any given day and to obtain the highest efficiency, it is necessary to design a solar still with as low a water depth as possible. It can be seen that the efficiency varies from $45 \%$ to $54 \%$ for $Z_{H}=1$ (Figure $3 a$ ); from $24 \%$ to $40 \%$ for $Z_{H}=11$ (Figure $3 \mathrm{~b}$ ); from $5 \%$ to $20 \%$ for $Z_{H}=50$ (Figure $3 \mathrm{c}$ ); and from $4 \%$ to $14 \%$ for $Z_{H}=90$ (Figure $3 \mathrm{~d}$ ). It is therefore desirable to construct the dimensionless water basin as small as possible.

Figures 4 and 5 show that the efficiency increases with increasing $G^{*}$ and increasing incident solar radiation (related to $\left.F_{I T}\right)$. This is consistent with the physics of the phenomena and similar reports (Garg and Mann, 1976; Al-Hinai et al., 2002; Tiwari and Tiwari, 2007; Xiao et al., 2013; Rahbar et al., 2015; Nguyen et al., 2017; Sarkar et al., 2017; Selvaraj and Natarajan, 2018; Varun Raj and Manokar, 2017). The factor $F_{I T}$ being equal to 1.2 means that the real solar radiation pattern from TMY was "hypothetically" multiplied by 1.2 , and the Dimensionless Solar Radiation Number $\left(C_{w c}^{*}\right)$ is also divided by the same factor.

It is very interesting to observe (Figure 4) that, in order to increase the areas ratio, it is necessary to design a solar still with a cover area that is higher than the basin area. It is recommended to design the solar still with different geometries than a traditional box (as in a single basin - single slope solar still). Examples of such different configurations involve a more inclined cover surface, a double-slope cover, a corrugate cover, a semi-spherical cover, or even a wick-type solar still, among others.

Figure 5 shows the importance of the solar radiation (Dimensionless Solar Radiation Number) on the still performance. The solar still efficiency is further increased when the basin is designed with a blackened baseliner and when increasing the incident solar radiation by using reflective materials. Some researchers suggest that basin materials like rubber and gravel can enhance absorption, storage and evaporation effects. Charcoal, black gravel or rock could be used according to Sarkar et al. (2017). Weather parameters, such as solar radiation, ambient temperature and wind velocity, can be uncontrollable as they depend on nature, on the time along a day and on the localization.

However, mixing dyes (like black naphthylamine dye) with water can help the water to absorb most of the heat from solar radiation, thereby increasing the distillate productivity (Abu-Hijleh, 2003; Rajvanshi, 1981). This is a direct result of changes in the water emissivity and absorptivity. Nijmeh et al. (2005) studied the enhancement of water productivity, using dissolved salts such as potassium permanganate and potassium dichromate, violet dye and charcoal. The addition of the dissolved salts is a novel method in improving the performance of solar stills. 
Figure 4 - Effect of areas ratio $\left(G^{*}\right)$ and the Fourier number on the on efficiency.

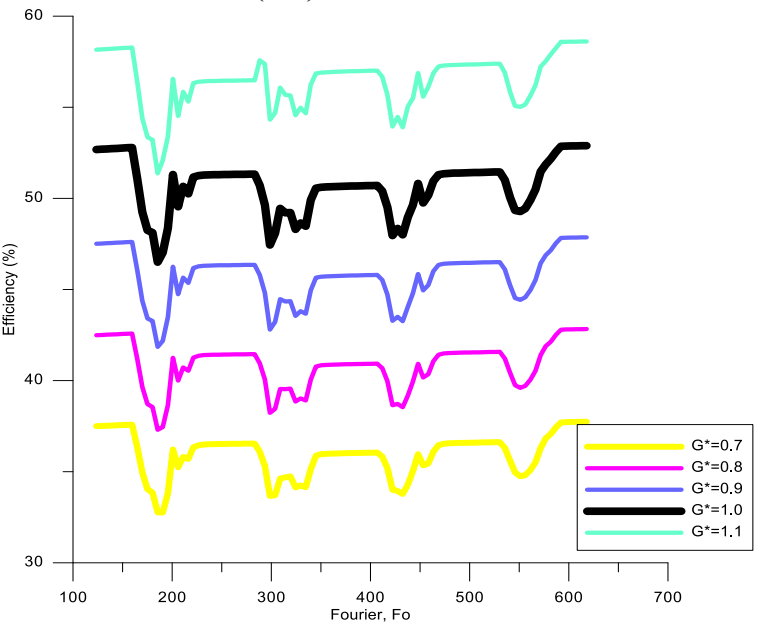

Source: Authors.

Figure 5 - Effect of increase in Dimensionless Solar Radiation Number $\left(C_{w c}^{*}\right)$ and the Fourier number on the efficiency.

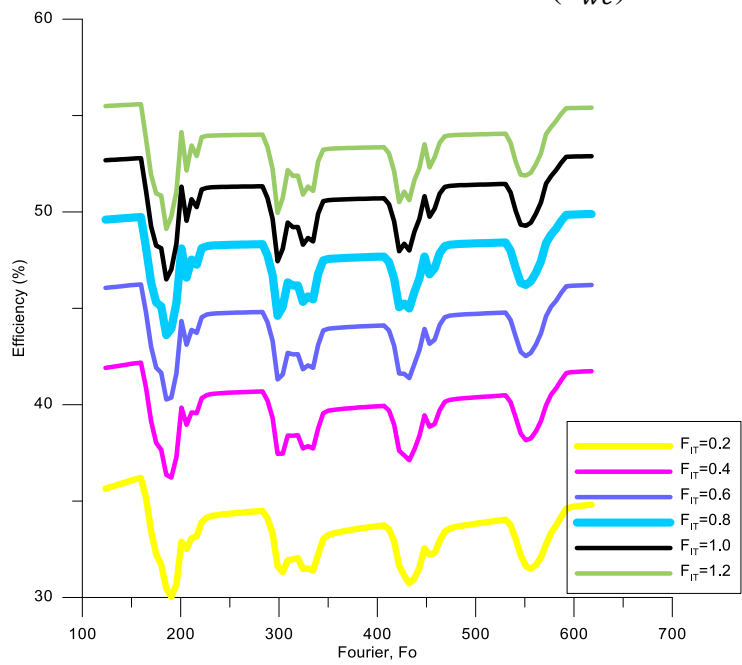

Source: Authors.

It can be seen in Figure 6a that lower loss Biot numbers (lower heat loss from the solar still) increase the efficiency. Even in the case of $1 / B i_{\text {Loss }}=16$, which means that there is practically no insulation in the solar still, the efficiency is the lowest. Figure $6 \mathrm{a}$ also shows that equilibrium is finally reached when $1 / B i_{\text {Loss }}$ is higher than 81 . In general, cotton, clothes, rubber, glass wool, mica sheets and wood, for example, can be good insulation materials (Sarkar et al., 2017). Al-Hinai et al. (2002) have shown that the optimal insulation thickness should lie between 0.09 and $0.13 \mathrm{~m}$.

When $1 / B i_{\text {Loss }}$ is larger than 81 , the resulting high dimensionless temperature difference between water in the basin and ambient environment (Figure 6b) will cause a relative increase in the dimensionless condensate mass flow (Figure 6c) and consequently higher efficiencies are obtained (Figure 6a). The results show that it is recommendable to adopt, in general, $1 / B i_{\text {Loss }}$ higher than 81 to minimize heat losses to the surroundings.

This saturation phenomenon on the temperature difference, mass flow and efficiency could be attributed to the balance between the heat transfer in the water by conduction and the thermal resistance related to the insulation. 
Figure 6a - Effects of the Loss Biot number $\left(B i_{L o s s}\right)$ and the Fourier number on the efficiency of a solar still.

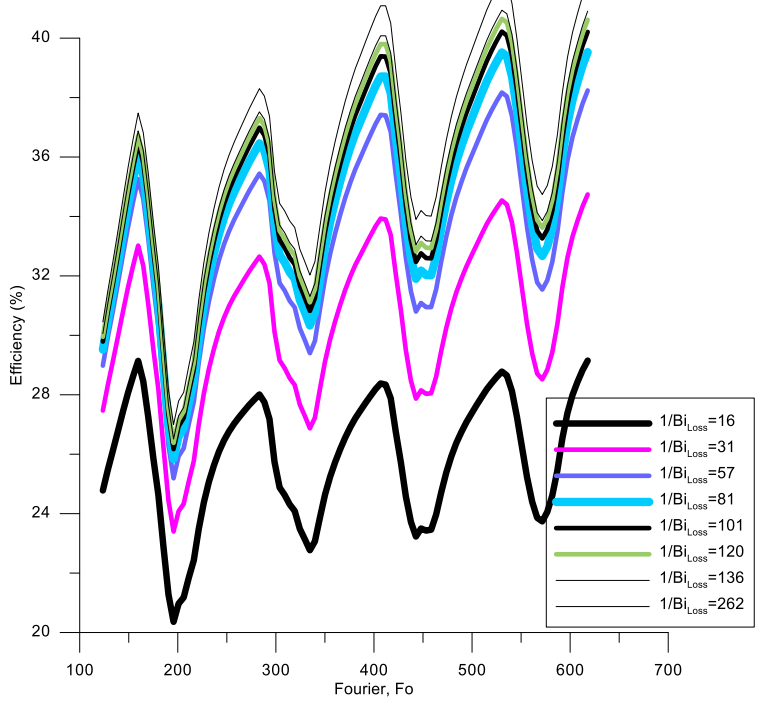

Source: Authors.

Figure $6 \mathbf{b}$ - Effects of the Loss Biot number $\left(B i_{\text {Loss }}\right)$ and the Fourier number on the dimensionless water temperature profiles.

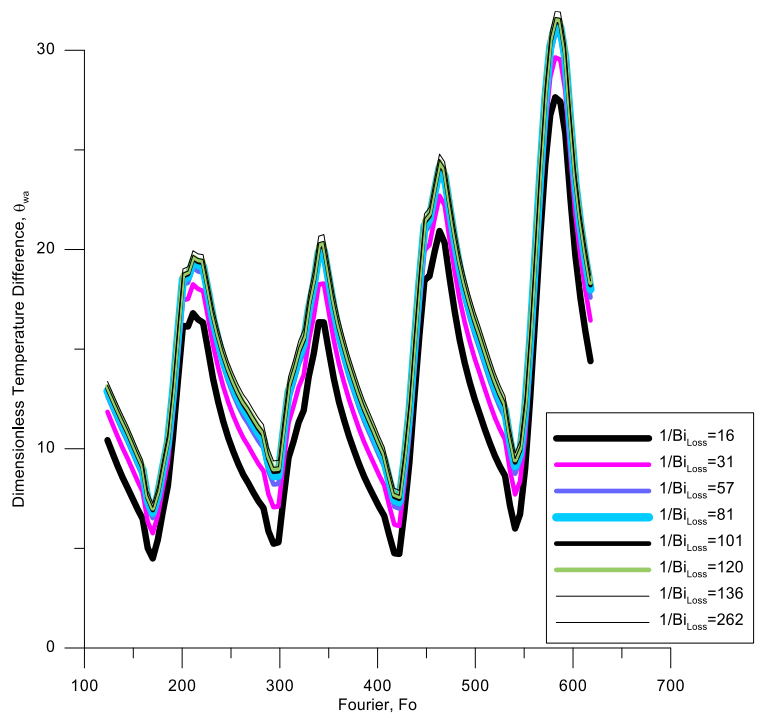

Source: Authors. 
Figure $\mathbf{6 c}-$ Effects of the Loss Biot number $\left(B i_{\text {Loss }}\right)$ and the Fourier number on the dimensionless condensate mass flow.

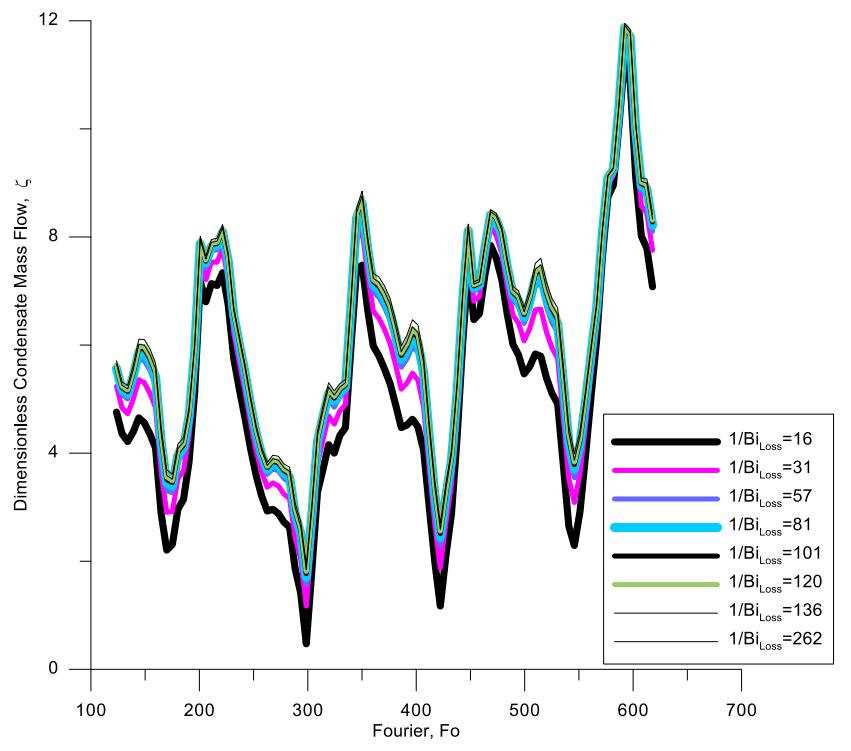

Source: Authors.

Figure 7 represents typical days for summer at Fortaleza, Brazil (DMS latitude and longitude coordinates are, respectively: $\left.3^{\circ} 43^{\prime} 1.99^{\prime \prime} \mathrm{S}, 38^{\circ} 32^{\prime} 35.02^{\prime \prime} \mathrm{W}\right)$. Considering the weather conditions of Figure 7, the variation of the efficiency and the dimensionless condensate mass flow with increasing Wind Biot number $\left(B i_{\text {Wind }}\right)$ is represented in Figures $8 \mathrm{a}$ and $8 \mathrm{~b}$, respectively. These results show that, by increasing the Wind Biot Number (in other words, increasing the wind velocity), the difference in temperature between the water and the cover surface is increased, and consequently the solar still performance is enhanced. The same conclusion can be made from the data depicted in Figures 9a, 9b, 9c and 9d, for the same range of the Fourier number. It must be reminded that the Wind Biot Number is a function of the convective heat transfer coefficient, which depends on the wind velocity.

In summary, the results shown in Figures 2 through 9 demonstrate that the dimensionless temperature difference between water and cover $\left(\theta_{\mathrm{wc}}\right)$; the dimensionless condensate mass flow $(\zeta)$, the efficiency $\left(\eta_{T}\right)$ and the Water Biot Number $\left(B i^{w}\right)$ change gradually with the Fourier number, and reach maximal values in the afternoon. This is due to the fact that the absorbed energy excels the heat losses from the solar still. This is clearly indicated in Figures 8a, 8b, 9a, 9b, 9c and 9d.

The variation of the dimensionless condensate mass flow (or, in a dimensional form, the water condensate mass flow rate) with a "hypothetical" increase in the daily wind profile by a factor $F_{\text {Wind }}$ is also highlighted. An increase factor of $1.2 \mathrm{implies}$ an increase of the same magnitude in the Wind Biot Number $\left(B i_{\text {Wind }}\right)$. Figure $8 \mathrm{~b}$ clearly indicates that the best performance was obtained close to noon. The value of $\zeta$ is about 8 , for a wind real pattern from TMY data, best viewed in Figure 9a; also, $\zeta$ is about 5 , for a reduction by a factor of $25 \%$, and $\zeta$ is about 11 for an increment of $500 \%$. 
Figure 7 - Meteorological Data: solar radiation and ambient temperature.

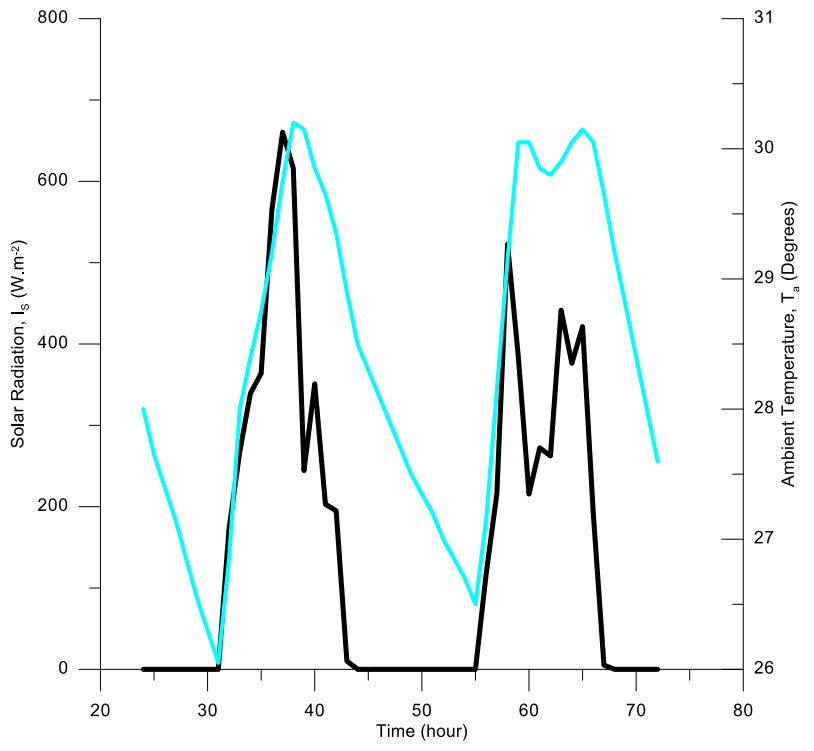

Source: Authors.

Figure 8a - Effects of the Wind Biot number $\left(B i_{W i n d}\right)$ and the Fourier number on the efficiency of a solar still.

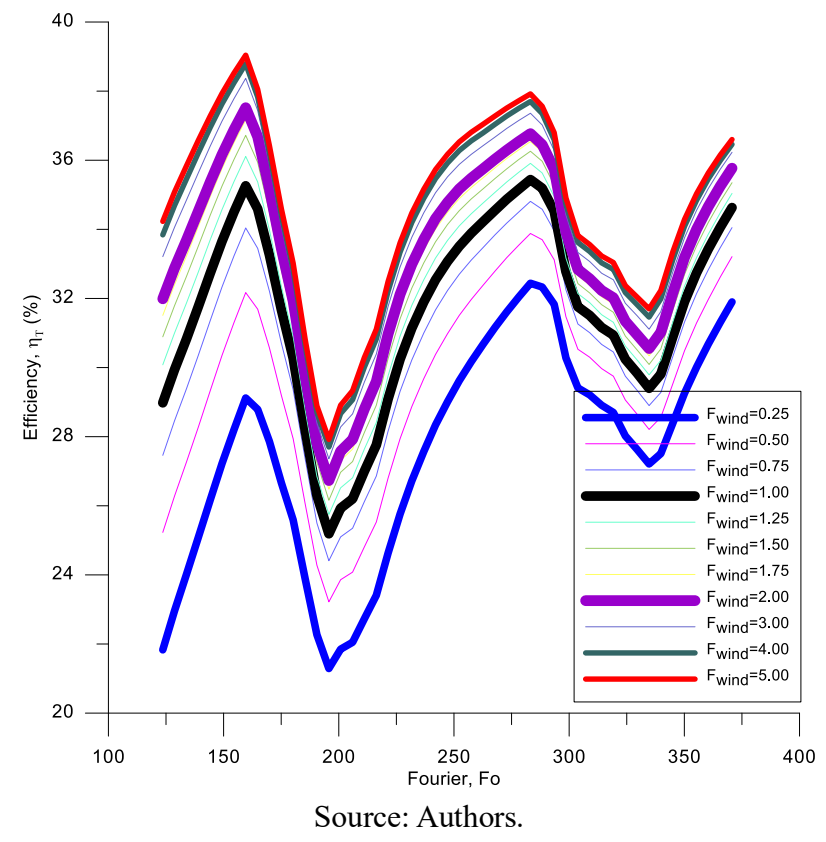


Figure 8b-Effects of the Wind Biot number $\left(B i_{\text {Wind }}\right)$ and the Fourier number on the dimensionless condensate mass flow.

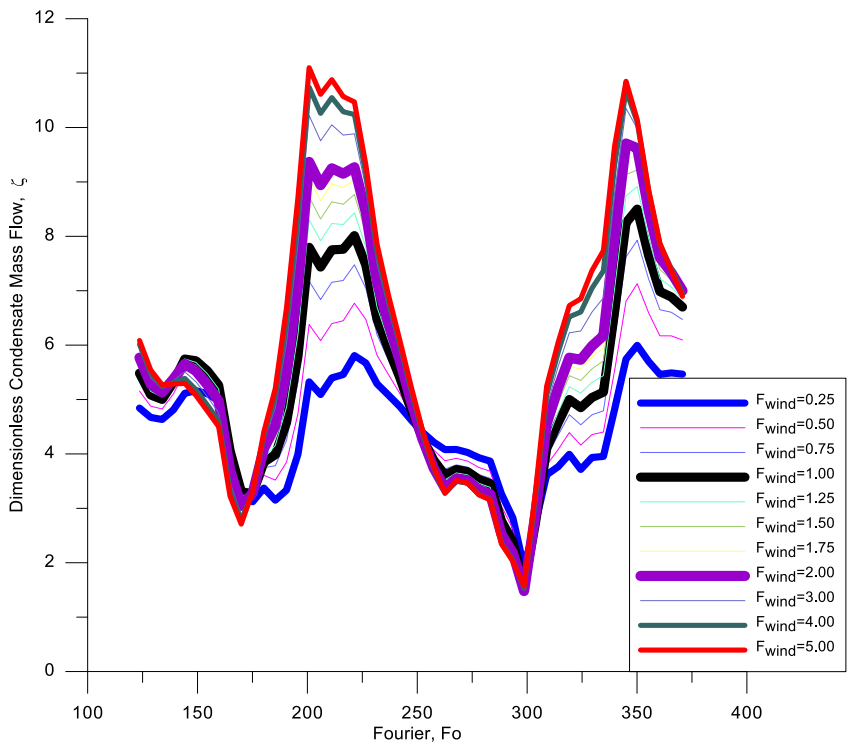

Source: Authors.

Figure 9a - Effects of the Fourier number on the efficiency and dimensionless water condensate mass flow for $Z_{H}=11$.

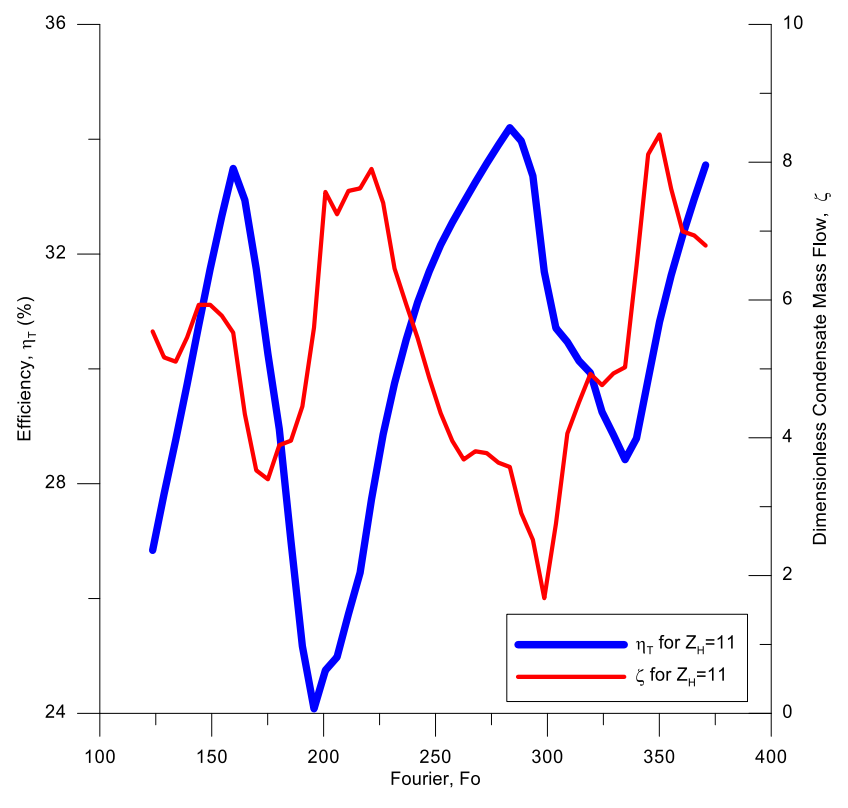

Source: Authors. 
Figure 9b-Effects of the Fourier number on the efficiency and dimensionless temperature difference between water and ambient environment for $Z_{H}=11$.

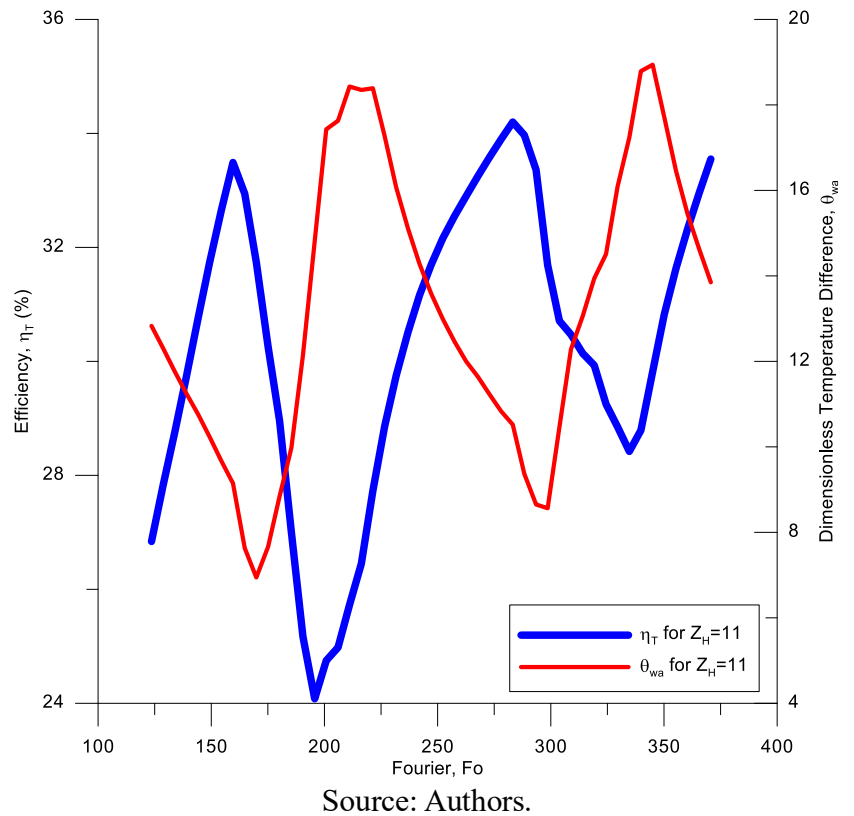

Figure 9c- Effects of the Fourier number on the efficiency and dimensionless temperature difference between water and cover for $Z_{H}=11$.

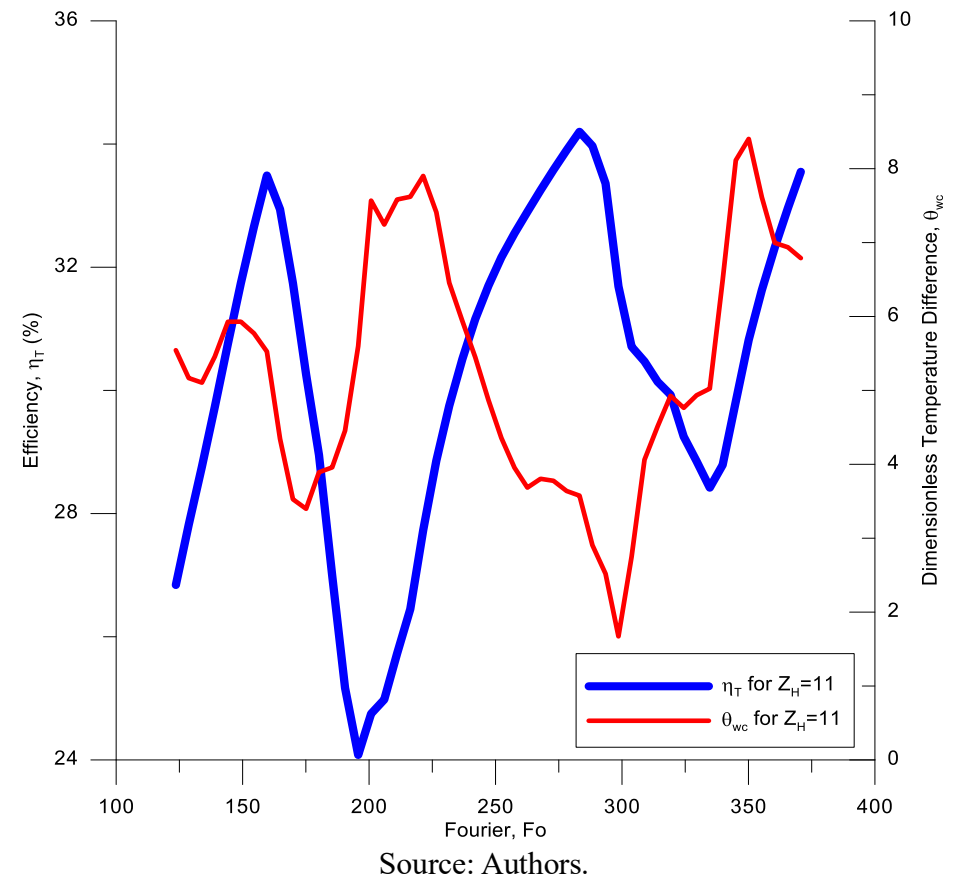

According to Equation 7, it is interesting to point out that, if $G^{*}$ equals 1 (the cover area is equal to the basin area), the value of the dimensionless condensate mass flow equals the dimensionless temperature difference between water and cover. Figures $9 \mathrm{a}$ and $9 \mathrm{c}$ should be compared. It is possible to estimate the condensate mass flow from the temperature difference between the water in the basin and the cover temperature. 
Figure 9d- Effects of the Fourier number on the efficiency and the Water Biot Number $\left(B i^{w}\right)$ for $Z_{H}=11$.

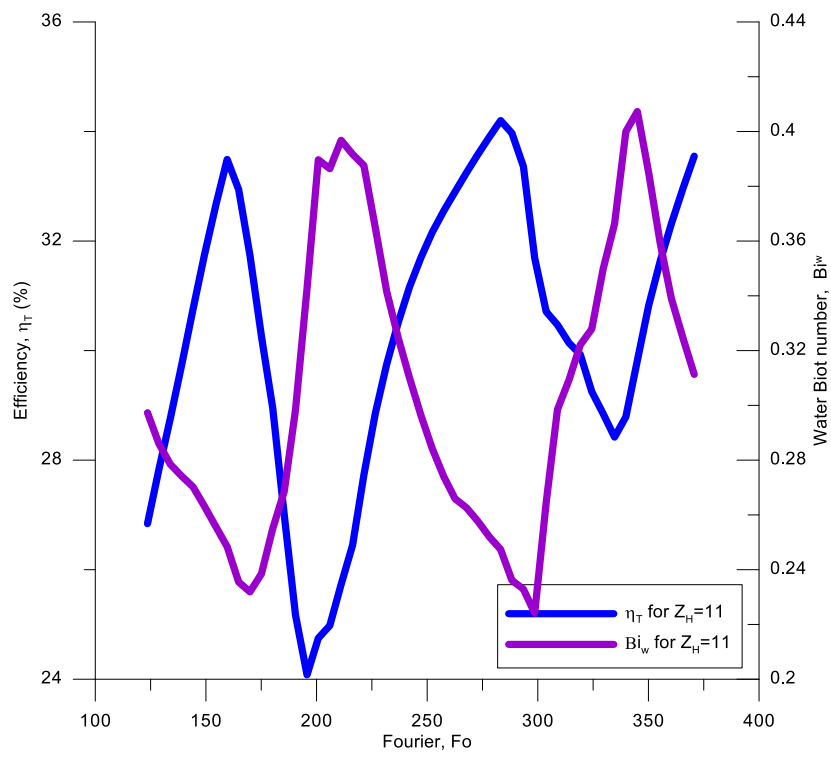

Source: Authors.

\section{Conclusion}

An appropriate global normalization of governing equations for a solar still is described and implemented in the present paper. Dimensionless numbers are of key importance in parametric analyses of engineering problems, mainly in fluid mechanics, heat and mass transfer studies. Dimensional analysis is an indispensable tool in this process and is used with three purposes, namely classification, measurement and simplification of physical laws. In this investigation, an optimization procedure involving 11 dimensionless groups which characterize the thermal performance of a passive solar still, including the Fourier Number, has been successfully proposed. The design of solar still systems plays an important role in the thermal performance. They are useful to understand the similarity among problems belonging to the same broad class. Thermal modeling helps designing solar stills by considering the best governing operating parameters.

This global approach focused on presenting five (5) characteristic parameters that are considered in parametric analyses: the Dimensionless Water Basin Number $\left(Z_{H}\right)$; the Areas Ratio Number $\left(G^{*}\right)$; the Dimensionless Solar Radiation Number $\left(C_{w c}^{*}\right)$; Loss Biot Number $\left(B i_{\text {Loss }}\right)$; and Wind Biot Number $\left(B i_{\text {Wind }}\right)$. The results showed that it is desirable to construct dimensionless water basin number, $Z_{H}$, "as small as possible" (Garg and Mann, 1976; Phadatare and Verma, 2007; Tiwari and Tiwari, 2007), which might be corresponding to the water deep of $10 \mathrm{~cm}$ or lower (Sarkar et al., 2017).

It is also very interesting to observe that, in order to increase the areas ratio, it is sufficient to design a solar still with a higher cover area than the basin area. The nondimensional analysis shows the importance of the solar radiation (Dimensionless Solar Radiation Number) on the still performance. The results also demonstrated that it is generally recommendable to adopt $1 / B i_{\text {Loss }}$ larger than 81 to minimize heat losses to the surroundings. Furthermore, when increasing the Wind Biot Number (or the wind velocity), the difference in temperature between the water and the cover surface is enhanced, and consequently the solar still performance is increased, as indicated by improved efficiency and dimensionless condensate mass flow. It is possible to estimate the value of the dimensionless condensate mass if the dimensionless temperature difference between water and cover is known. This is an important contribution of this analytical work. With the similarity theory that has been applied, experiments on solar stills could be conducted in a broader set of conditions, regardless of the geometric and/or operational parameters of the model, which can or cannot be consistent with those of the prototype. Such versatility greatly helps improving the efficiency of the equipment. 
The results also indicated that the generalized dimensionless model could be able of predicting the still performance. The reasons and processes behind the changing trends of the results depend on the simple analysis of the corresponding nondimensional number.

The robustness of the model was ensured by such parameters as the dimensionless temperature difference between water in the basin and ambient environment $\left(\theta_{\mathrm{wa}}\right)$, the dimensionless temperature difference between water and cover $\left(\theta_{\mathrm{wc}}\right)$, the dimensionless condensate mass flow $(\zeta)$, and the efficiency $\left(\eta_{T}\right)$, in agreement with published reports. The generalized dimensionless model is simple and considers all geometric, operational and meteorological parameters by processing only four equations. Therefore, it is useful in the design and optimization of solar stills, with several technological applications, particularly in water treatment and energy plants.

This work was successful in introducing, applying and discussing a novel approach for the analysis of the behavior and performance of solar stills to the scientific and academic communities. The proposal to go beyond the restricted description of individual behaviors that have been reported is highlighted, with the optimization of experimental conditions and implementation of an appropriate global normalization employing dimensionless numbers.

\section{Acknowledgements}

The authors thank the support of the Universidade Federal de Viçosa (UFV), the scholarship grantees and volunteers, as well as the professors, technicians and students who have helped developing this study. Partial finance granted by Coordenação de Aperfeiçoamento de Pessoal de Nível Superior (CAPES, Brazil - Finance Code 001) is also gratefully acknowledged.

\section{Nomenclature}

Dimensional variable:

$A_{b}=$ Area of the basin of the still, $\left[\mathrm{m}^{2}\right]$

$A_{c}=$ Cover surface area $\left[\mathrm{m}^{2}\right]$

$c p_{w}=$ Specific heat of water $\left[\mathrm{J} \mathrm{kg}^{-1} \mathrm{~K}^{-1}\right]$

$h f g=$ Latent heat of vaporization $[\mathrm{Jkg}]$

$h_{1 g}=$ Convective heat transfer coefficient between the cover and the surroundings [ $\mathrm{W} \mathrm{m}^{-2} \mathrm{~K}^{-1}$ ]

$h_{t w}=$ Total heat transfer coefficient from the water surface to the cover surface $\left[\mathrm{W} \mathrm{m} \mathrm{m}^{-2} \mathrm{~K}^{-1}\right]$

$\overline{H_{b}}=$ Reference water depth $(=0.01 \mathrm{~m})$

$I_{S}=$ Solar radiation $\left[\mathrm{W} \mathrm{m}^{-2}\right]$

$m_{w}=$ Mass of water in the basin $[\mathrm{kg}]$

$T_{a}=$ Ambient temperature $[\mathrm{K}]$

$\bar{T}_{a}=$ Reference ambient temperature $[\mathrm{K}]$

$T_{c}=$ Cover temperature $[\mathrm{K}]$

$T_{w i}=$ Reference basin water temperature $[\mathrm{K}]$

$T_{w}=$ Basin water temperature $[\mathrm{K}]$

$U_{s}=$ Heat loss coefficient from the insulation $\left[\mathrm{W} \mathrm{m}{ }^{-2} \mathrm{~K}^{-1}\right]$

$\alpha_{c}=$ Absorptivity of the cover $\left[\mathrm{J} \mathrm{kg}^{-1}\right]$

$\alpha_{w}=$ Absorptivity of the water

$\rho_{w}=$ Specific mass of water $\left[\mathrm{kg} \mathrm{m}^{-3}\right]$ 
Nondimensional variable:

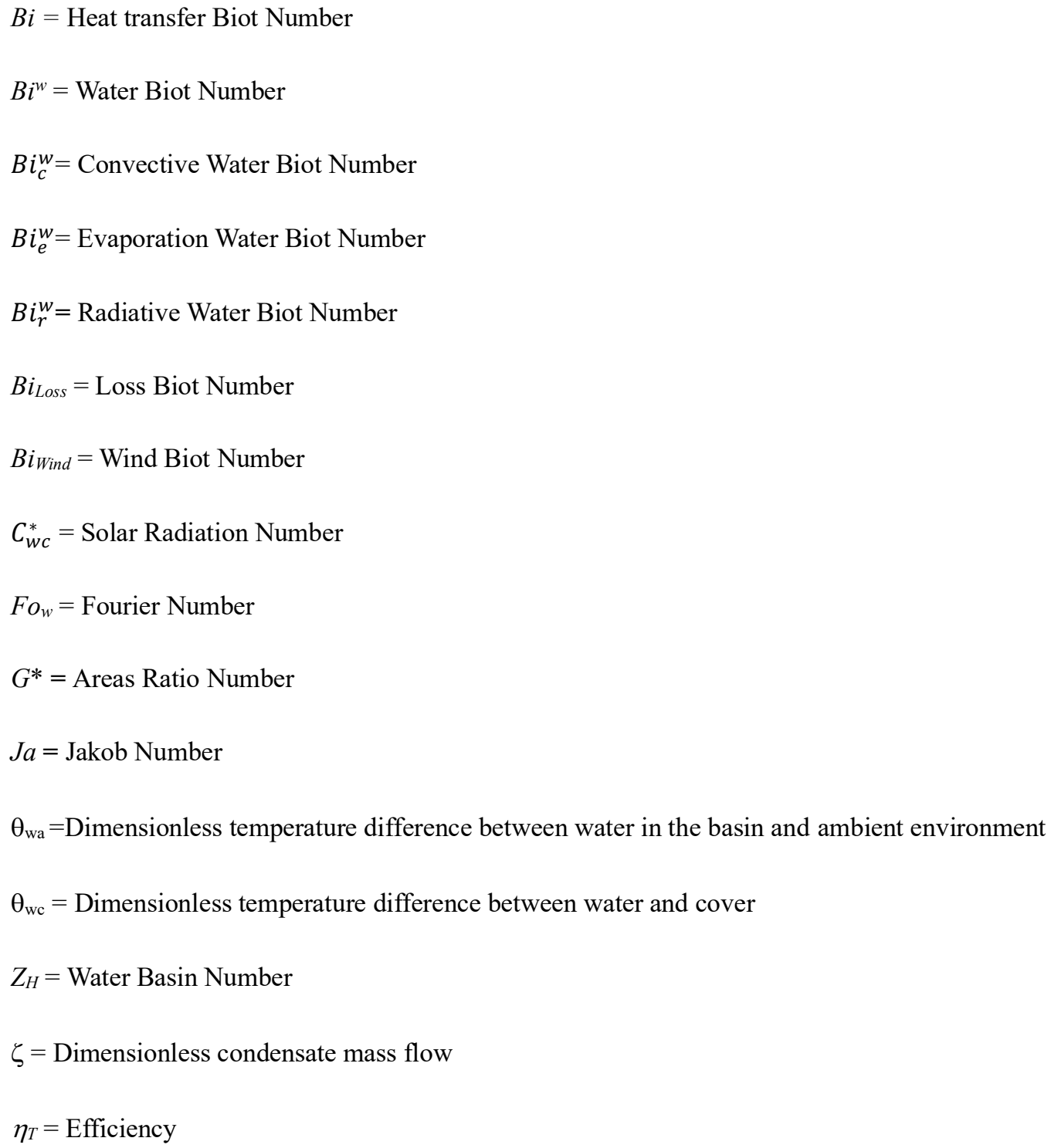

\section{References}

Abu-Hijleh, B. A. (2003). Effect of water emissivity on solar still efficiency. International Journal of Sustainable Energy, 23(1-2), 13-19.

Afrand, M., Kalbasi, R., Karimipour, A., \& Wongwises, S. (2016). Experimental investigation on a thermal model for a basin solar still with an external reflector, Energies, 10(18), https://doi.org/10.3390/en10010018.

Agrawal, A., Rana. R. S., \& Srivastavaa, P. K. (2017). Heat transfer coefficients and productivity of a single slope single basin solar still in Indian climatic condition: Experimental and theoretical comparison. Resource-Efficient Technologies 3, 466-482.

Agrawal, A., \& Rana. R. S. (2019). Theoretical and experimental performance evaluation of single-slope single-basin solar still with multiple V-shaped floating wicks. Heliyon 5, Issue 4, e01525.

Ahmed, H. M.; \& Alfaylakawi, K. A. (2012). Productivity enhancement of conventional solar stills using water sprinklers and cooling fan. Journal of Advanced Science and Engineering Research, 2(3), 168-177.

Ahsan, A.; Imteaz M.; Rahman A.; Yusuf B.; \& Fukuhara T. (2012). Design, fabrication and performance analysis of an improved solar still. Desalination, 292, $105-112$.

Al-Hayeka, I.; \& Badran, O. O. (2004). The effect of using different designs of solar stills on water distillation. Desalination, 169(2), $121-127$. 
Al-Hinai, H., AL-Nassri, M. S., \& Jubran, B. A. (2002). Effect of climatic, design and operational parameters on the yield of a simple solar still. Energy Conversion and Management, 43(13), 1639-1650.

Al-Karaghouli, A.; Renne, D.; \& Kazmerski, L. L. (2009). Solar and wind opportunities for water desalination in the Arab regions. Renewable and Sustainable Energy Reviews, 13(9), 2397-2407.

Argiriou, A., Lykoudis, S., Kontoyiannidis, S., Balaras, C.A., Asimakopoulos, D., Petrakis, M., \& Kassomenos, P. (1999). Comparison of methodologies for TMY generation using 20 years data for Athens, Greece, Solar Energy, 66(1), 33-45.

Arunkumar, T., Jayaprakash R., Denkenberger D., Ahsan A., Okundamiya M. S., Kumar, S., Tanaka H., \& Aybar, A. S. (2012). An experimental study on a hemispherical solar still. Desalination, 286, 342-348.

Ayoub, G. M., Al-Hindi, M.; \& Malaeb, L. (2015). A solar still desalination system with enhanced productivity. Desalination and water treatment, 53(12), 31793186.

Bergman, T. L., A. S., \& Lavine, F. P. Incropera (2011). Fundamentals of Heat and Mass Transfer. John Wiley \& Sons, Hoboken, NJ, United States.

Buckingham, E. (1914). On physically similar systems: illustrations of the use of dimensional equations, Physical Review, 4, 345-376.

Çengel, Y. A. \& Bones, M. A. (2008). Thermodynamics: An Engineering Approach. Boston: McGraw-Hill Higher Education.

Dash, S. K. (2014). Engineering Equation Solver: application to engineering and thermal engineering problems, Oxford, U.K.: Alpha Science International Ltd.

Duffie, J. A. \& Beckman, W. A. (1991). Solar Engineering of Thermal Processes, John Wiley and Sons, New York.

Dunkle, R. V. (1961). Solar Water Distillation, the Roof Type Solar Still and Multiple Effect Diffusion Still. Developments in Heat Transfer, ASME, Proceedings of the International Heat Transfer, Part V, University of Colorado, Vol. 895.

Edalatpour, M., Aryana, K., Kianifar, A., Tiwari, G. N., Mahian, O., \& Wongwises, S. (2016). Solar stills: A review of the latest developments in numerical simulations, Solar Energy, 135, 897-922.

Elango, C., N. Gunasekarn, \& Sampathkumar, K. (2015). Thermal Models of Solar Still - A Comprehensive Review. Renewable and Sustainable Energy Reviews 47: 856-911.

El-Bahi, A.; \& Inan, D. (1999). A solar still with minimum inclination, coupled to an outside condenser. Desalination, 123(1), 79-83.

El-Ghonemy, A. M.K. (2012). Water desalination systems powered by renewable energy sources: Review. Renewable and Sustainable Energy Reviews 16, 1537 -1556 .

Elkader, M. A. (1998). An Investigation of the parameters involved in simple solar still with inclined yute. Renewable Energy, 14(1-4), 333-338.

Eze, J. I.; \& Ojike, O. (2012). Comparative evaluation of rectangular and pyramid-shaped solar stills using saline water. International Journal of Physical Sciences, 7(31), 5202-5208.

Garg, H. P., \& Mann, H. S. (1976). Effect of climatic, operational and design parameters on the year round performance of single-sloped and double sloped solar still under Indian arid zone conditions. Solar Energy, 18(2), 159-163.

Gnanaraj, S. J. P., \& Velmurugan, V. (2019). An experimental study on the efficacy of modifications in enhancing the performance of single basin double slope solar still, Desalination, 467, 12-28.

Kalogirou, S. A. (2003). Generation of typical meteorological year (TMY-2) for Nicosia, Cyprus, Renewable Energy, 28(15), $2317-2334$.

Karagiannis, I. C.; \& Soldatos, P. G. (2008). Water desalination cost literature: review and assessment. Desalination, 223(1-3), 448-456.

Khalifa, A. J. N., \& Hamood, A. M. (2009). On the verification of the effect of water depth on the performance of basin type solar stills, Solar Energy, 83(8), $1312-1321$

Kumar, P. V., Kumar, A., Prakash, O., \& Kaviti, O. K. (2015). Solar stills system design: A review, Renewable and Sustainable Energy Reviews, 51, 153-181.

Kunes, J. (2012). Dimensionless Physical Quantities in Science and Engineering, Elsevier.

Madhlopa, A., \& Johnstone, C. (2009). Model for computation of solar fraction in a single-slope solar still, Solar Energy, 83(6), 873-882.

Martins, F. R., Abreu, S. L., \& Pereira, E. B. (2012). Scenarios for solar thermal energy applications in Brazil, Energy Policy, 48, 640-649.

Mashaly, A.F., Alazba, A. A., Al-Awaadh, A. M., \& Mattar, M. A. (2015). Predictive model for assessing and optimizing solar still performance using artificial neural network under hyper arid environment, Solar Energy, 118, 41-58.

Mohan, I., Yadav, S., Panchal, H., \& Brahmbhatt, S. (2019). A review on solar still: a simple desalination technology to obtain potable water, International Journal of Ambient Energy, 40:3, 335-342.

Mowla, D., \& Karimi, G. (1995). Mathematical modelling of solar stills in Iran, Solar Energy, 55(5), 389-393.

Muftah, A. F., Alghoul, M. A., Fudholi, A., Abdul-Majeed, M. M., \& Sopian, K. (2014). Factors affecting basin type solar still productivity: A detailed review. Renewable and Sustainable Energy Reviews 32, 430-447. 
Nguyen, T. B. (2017). Factors affecting the yield of solar distillation systems and measures to improve productivity, Desalination and Water Treatment, 68: 91 98 .

Nijmeh, S., Odeh, S., \& Akash, B. (2005). Experimental and theoretical study of a single - basin solar still in Jordan, Int. Comm. Heat Mass Transfer, 32, 565572 .

Omara, Z. M., Kabeel, A. E., \& Abdullah, A. S. (2017). A review of solar still performance with reflectors, Renewable and Sustainable Energy Reviews, 68(1), 638-649.

Oresta, P., Verzicco, R., Lohse, D., \& Prosperetti, A. (2009). Heat transfer mechanisms in bubbly Rayleigh-Bénard convection. In: Eckhardt B. (eds) Advances in Turbulence XII. Springer Proceedings in Physics, vol 132. Springer, Berlin, Heidelberg.

Phadatare, M. K., \& Verma, S. K. (2007). Influence of water depth on internal heat and mass transfer in a plastic solar still. Desalination, 217(1-3). 267-275.

Panchal, H. N., \& Shah, P. K. (2011). Effect of Varying Glass cover thickness on Performance of Solar still: in a Winter Climate Conditions. International Journal of Renewable Energy Research (IJRER), 1(4), 212-223.

Radhwan, A. M. (2005). Transient performance of a stepped solar still withbuilt-in latent heat thermal energy storage. Desalination, $171(1), 61-76$.

Rahbar, N., Esfahani, J. A. \& Fotouhi-Bafghi, E. (2015). Estimation of convective heat transfer coefficient and water-productivity in a tubular solar still-CFD simulation and theoretical analysis. Solar Energy, 113, 313-323.

Raj, S. V.; \& Manokar, A. M. (2017). Design and Analysis of Solar Still. Materials Today: Proceedings, 4(8), 9179-9185.

Rajan, A. Senthil; Raja, K.; \& Marimuthu, P. (2014). Multi basin desalination using biomass heat source and analytical validation using RSM. Energy conversion and management, 87, 359-366.

Rajaseenivasan, T.; \& Murugavel, K. K. (2013). Theoretical and experimental investigation on double basin double slope solar still. Desalination, 319 , 25-32.

Rajaseenivasan, T.; Raja, P. Nelson; \& Srithar, K. (2014). An experimental investigation on a solar still with an integrated flat plate collector. Desalination, 347, 131-137.

Rajvanshi, A. K. (1981). Effect of various dyes on solar distillation. Solar Energy, 27(1), 51-65.

Rashidi, S., Esfahani, J. A., \& Rahbar, N. (2017). Partitioning of solar still for performance recovery: Experimental and numerical investigations with cost analysis, Solar Energy, 153, 41-50.

Rufuss, D. D. W., Iniyan, S., Suganthi, L., \& Davies, P. A. (2016). Solar stills: A comprehensive review of designs, performance and material advances, Renewable and Sustainable Energy Reviews, 63, 464-496.

Ruzicka, M. C. (2008). On dimensionless numbers, Chemical Engineering Research and Design, 86(8), 835-868.

Sarkar, M. N. I., Sifat, A. I., Reza, S. M. S. et al. (2017). A review of optimum parameter values of a passive solar still and a design for southern Bangladesh. Renewables, 4: 1.

Selvaraj, K., \& Natarajan, A. (2018). Factors influencing the performance and productivity of solar stills - A review, Desalination, 435 , Pages $181-187$.

Shawaqfeh, A. T. \& Farid, M. M. (1995). New Development in the Theory of Heat and Mass Transfer in Solar Stills. Solar Energy, 55, $527-535$.

Sivakumar, V.; \& Sundaram, E. G. (2013). Improvement techniques of solar still efficiency: A review. Renewable and Sustainable Energy Reviews, $28,246-264$.

Tayeb, A. M. (1992). Performance study of some designs of solar stills. Energy conversion and management, 33(9), 889-898.

Tiwari, A. K., \& Tiwari, G. N. (2007). Thermal modeling based on solar fraction and experimental study of the annual and seasonal performance of a single slope passive solar still: The effect of water depths. Desalination, 207(1-3), 184-204.

Tiwari, G. N., Dimri, V., \& Chel, A. (2009). Parametric study of an active and passive solar distillation system: Energy and exergy analysis, Desalination, 242(13), 1-18.

Tiwari, G. N., \& Sahota, L. (2017). Advanced Solar-Distillation Systems Basic Principles, Thermal Modeling, and Its Application. SpringerLink.

Tripathi, R., \& Tiwari, G. N. (2006). Thermal modeling of passive and active solar stills for different depths of water by using the concept of solar fraction, Solar Energy, 80(8) 956-967.

Tsilingiris, P. T. (2009). Analysis of the heat and mass transfer processes in solar stills - The validation of a model, Solar Energy, 83(3), 420-431.

Tsilingiris, P. T. (2010). Modelling heat and mass transport phenomena at higher temperatures in solar distillation systems - the Chilton-Colburn analogy. Solar Energy 84, 308-317.

Tsilingiris, P. T. (2011). Prediction and measurements of mass transport in experimental solar stills. Solar Energy 85, 2561-2570.

Tsilingiris, P. T. (2012). Combined heat and mass transfer analyses in solar distillation systems - The restrictive conditions and a validity range investigation. Solar Energy 86, 3288-3300.

Varun RAJ, S., \& Manokar, A. M. (2017). Design and Analysis of Solar Still, Materials Today: Proceedings, 4(8), $9179-9185$. 
Research, Society and Development, v. 10, n.1, e26910111304, 2021

(CC BY 4.0) | ISSN 2525-3409 | DOI: http://dx.doi.org/10.33448/rsd-v10i1.11304

Varun, A. K. (2010). Solar stills: A review, Renewable and Sustainable Energy Reviews, 14(1), 446-453.

Velmurugan, V., et al. (2008). Productivity enhancement of stepped solar still: Performance analysis. Thermal Science, 12(3), 153-163.

Velmurugan, V., K., \& Srithar, K. (2011). Performance analysis of solar stills based on various factors affecting the productivity - a review, Renew. Sust. Energ. Rev. 15, 1294-1304.

Voropoulos, K., Mathioulakis, E., \& Belesiotis, V. (2000). Transport phenomena and dynamic modeling in greenhouse type solar stills. Desalination 129, 273281.

Welty, J. R., Wicks, C. E., Wilson, R. E., \& Rorrer, G. (2007). Fundamentals of Momentum, Heat, and Mass Transfer, (5th ed.), Publisher John Wiley \& Son.

Xiao, G., Wang, X., Ni, M., Wang, F., Zhu, W., Luo, Z., \& Cen, K. (2013). A review on solar stills for brine desalination, Applied Energy, $103,642-652$.

Yarin, L. P. (2012). The Pi-Theorem: Applications to Fluid Mechanics and Heat and Mass Transfer. Springer-Verlag Berlin Heidelberg.

Zhou, W., Lou, C., Li, Z., Lu, L., \& Yang, H. (2010). Current status of research on optimum sizing of stand-alone hybrid solar-wind power generation systems, Applied Energy, 87(2), 380-389. 